\title{
FEATURES OF FUNCTIONING OF THE IMMUNE SYSTEM UNDER STRESS
}

\author{
N.S. Zaitseva, L.P. Syziakina
}

Department of Clinical Immunology and Allergology, Rostov state medical university, Rostov-on-Don, Russia

\section{ОСОБЕННОСТИ ФУНКЦИОНИРОВАНИЯ ИММУННОЙ СИСТЕМЫ В УСЛОВИЯХ СТРЕССОВЫХ НАГРУЗОК}

\author{
Н.С. Зайцева, Л.П. Сизякина \\ Кафедра клинической иммунологии и аллергологии ФПК и ППС \\ ФГБОУ ВО «Ростовский государственный медицинский университет» Минздрава России, \\ Ростов-на-Дону
}

The psychobiological essence of stress is to reprogram the resources of the human body for survival in extreme life-threatening conditions. The study of the activity of the main homeostatic systems in acute and prolonged adaptive reactions in soldiers is of great scientific and practical interest. The immune status was assessed in 42 military officers who participated in special operations for the first time. Not only quantitative, but also structural changes of the immune system function in the military-participants of special operations were revealed. The results require further analysis, study and consideration in assessing the health of soldiers.

Keywords: stress; immune system.

Психобиологическая сущность стресса заключается в перепрограммировании ресурсов человеческого организма на выживание в экстремальных жизнеопасных условиях. Изучение активности основных гомеостатических систем в условиях острых и пролонгированных адаптационных реакций у военнослужащих представляет большой научно-практический интерес. Оценка иммунного статуса проводилась у 42 военнослужащих-офицеров, впервые участвовавших в спецоперациях. Выявлены не только количественные, но и структурные изменения функции иммунной системы у военнослужащих-участников спецопераций. Полученные результаты требуют дальнейшего анализа, изучения и учета в оценке состояния здоровья военнослужащих.

Ключевые слова: стресс; иммунная система.

Introduction. In everyday life, one of the most powerful factors affecting the changes in the nervous, endocrine and immune systems is the psychoemotional or social stress [3]. The reaction to acute stress can serve as an endogenous psychophysiological adjuvant that enhances immune responses, however, prolonged activation under chronic stress can exacerbate immunopathology [1,2].

The purpose of the study: to trace changes in immune responses in soldiers under stress.

Materials and methods. 42 servicemen were examined (mean age 34,6 \pm 5.1 years) before, immediately after the first participation in their professional activities in special operations (the trip in the area with an intense operational environment duration -3 months). The control group was made by the military personnel by the nature of service never participating in special operations. Immune status was assessed by expression of $\mathrm{CD}^{+}, \mathrm{CD}^{+}$, $\mathrm{CD} 16^{+}, \mathrm{CD} 19^{+}$, Foxp3 in $\mathrm{CD} 4^{+} \mathrm{CD} 25^{+}$. Cytotoxic activity of lymphocytes was investigated by granzim b content in T-cytotoxic lymphocytes and NK cells (Becman Coulter, USA). Assessment of monocytic-macrophage level was studied by the number of $\mathrm{CD}_{14}{ }^{+} \mathrm{HLADR}^{+}$and expression of TLR2, TLR4, TLR9 on monocytes. The levels of serum immunoglobulin classes A, M, G was determined by ra- dial immunodiffusion in gel by Mancini. Statistical processing of the data was performed using a set of applications MS Office 2010, Statistica 6.0 for Windows. Significant differences between the indicators were determined at $p<0.05$.

Results. The quantitative preservation of adaptive reserves of T-lymphocytes was noted in the T-cell link, which was accompanied by a tendency to increase readiness for apoptosis $\left(\mathrm{CD}^{+} \mathrm{CD} 95^{+}\right)$, reduction of late activation potential in the general population $\left(\mathrm{CD}^{+} \mathrm{HLADR}^{+}\right)$and in $\mathrm{CD} 8^{+}$ lymphocyte subpopulation $\left(\mathrm{CD}^{+} \mathrm{HLADR}^{+}\right)$, with a significant decrease in the content of cytolytically active $\mathrm{CD} 8^{+}$-cells containing granzim $\left(\mathrm{CD}^{+} \mathrm{Gr}^{+}\right)$. The above changes were compensated by the increase in the activation potential of $\mathrm{CD} 4^{+}$lymphocyte subpopulation due to a significant increase in the expression of early activation markers $\left(\mathrm{CD} 4{ }^{+} \mathrm{CD} 25^{+}\right)$ and activation of suppressor function of T-regulatory cells $\left(\mathrm{CD} 4^{+} \mathrm{CD} 25^{+} \mathrm{Foxp}^{+}\right)$. Preservation of adaptive potential in the subjects confirmed the tendency to increase of immunoregulatory index. Changes in the effector link of innate immunity were determined by reducing the relative number of cells - natural killers after returning from a business trip and significant inhibition of their cytolytic activity by reducing the expression of granzim B $\left(\mathrm{CD} 16^{+} \mathrm{Gr}^{+}\right)$. In the 
Parameters of the immune status of soldiers, participants of special operations

\begin{tabular}{|c|c|c|}
\hline Indicators & Before participation in special operations & limmediately after participation in special operations \\
\hline $\mathrm{CD}^{+}, \%$ & $72.5 \pm 2.16$ & $76.5 \pm 2.15$ \\
\hline $\mathrm{CD}^{+} \mathrm{HLADR}^{+}, \%$ & $3.15 \pm 0.49$ & $2.05 \pm 0.96$ \\
\hline $\mathrm{CD}^{+} \mathrm{CD} 95^{+}, \%$ & $1.9 \pm 0.38$ & $3.5 \pm 1.2$ \\
\hline $\mathrm{CD}^{+}, \%$ & $42.5 \pm 2.07$ & $51 \pm 3.03$ \\
\hline $\mathrm{CD} 4^{+} \mathrm{CD} 25^{+}$ & $1.65 \pm 0.35$ & $4.7 \pm 0.49^{*}$ \\
\hline $\mathrm{CD} 4^{+} \mathrm{CD} 25^{+}$Foxp $3, \quad \%$ & $1.05 \pm 0.25$ & $2.4 \pm 0.37^{*}$ \\
\hline $\mathrm{CD}^{+}, \%$ & $28 \pm 2.3$ & $25.5 \pm 2.23$ \\
\hline $\mathrm{CD}^{+} \mathrm{HLADR}^{+}, \%$ & $2.8 \pm 0.47$ & $1.1 \pm 0.6^{*}$ \\
\hline $\mathrm{CD} 8^{+} \mathrm{Gr}^{+}, \%$ & $25 \pm 2.3$ & $15 \pm 3.4^{*}$ \\
\hline IRI & $1.55 \pm 0.19$ & $2.1 \pm 0.26$ \\
\hline $\mathrm{CD} 16^{+}, \%$ & $10.5 \pm 1.67$ & $7 \pm 2.9$ \\
\hline $\mathrm{CD} 16^{+} \mathrm{Gr}^{+}, \%$ & $8.5 \pm 1.6$ & $4.3 \pm 1.4^{*}$ \\
\hline $\mathrm{CD} 19^{+}, \%$ & $14.5 \pm 1.52$ & $5.5 \pm 1.9^{*}$ \\
\hline $\mathrm{CD}_{14}{ }^{+} \mathrm{HLADR}^{+}, \%$ & $60 \pm 3.5$ & $68 \pm 3.85$ \\
\hline TLR282 & $66 \pm 3.5$ & $49 \pm 4.8^{*}$ \\
\hline TLR284 & $30 \pm 4.5$ & $10 \pm 2.5^{*}$ \\
\hline TLR289 & $7.5 \pm 1.25$ & $5 \pm 0.88$ \\
\hline
\end{tabular}

humoral link of the immune system marked a significant inhibition of the synthesis of B-lymphocytes with preserved immunoglobulin-producing function. Analysis of the functional activity of monocytic cells revealed the preservation of their atigen-presenting function $\left(\mathrm{CD} 14^{+} \mathrm{HLADR}^{+}\right)$. There was a significant decrease in the expression of surface TLR282 and TLR284 (tabl. 1).
Conclusion. Even short-term (up to 3 months) participation in special operations leads to significant violations of the immune status in the form of changes in the functional activity of T-lymphocytes, oppression from the processes of maturation of cells-natural killers and B-lymphocytes. The mechanisms of the revealed changes are interesting, which requires further monitoring of the subjects.

\section{References}

1. Zaitseva NS, Sizyakina LP. Dysfunction of the immune system in the structure of comorbid pathology in military veterans of military operations in the remote period of observation. Immunology. 2016;37(5):267-270.

2. Firdaus S. Enhancing versus Suppressive Effects of Stress on Immune Function: Implications for Immunoprotection and Immunopathology. Neuroimmunomodulation. 2009;16(5):300-317.

3. Verburg-van Kemenade BM, Cohen N, Chadzinska M. Neuroendocrine-immune interaction: Evolutionarily conserved mechanisms that maintain allostasis in an ever-changing environment. Dev. Comp. Immunol. 2017;66:2-23. 